\title{
Clinical, Salivary and Bacterial Markers on the Orthodontic Treatment
}

\author{
Edith Lara-Carrillo \\ Faculty of Dentistry, Autonomous University of the State of Mexico, \\ Mexico
}

\section{Introduction}

Malocclusions are defined by different clinical signs, dental, aesthetic, functional and skeletal parameters. Numerous local factors can interfere with the adequate maxillary and mandible growth, which it can induce to the development of dentoskeletal alterations (Migale et al., 2009).

The Orthodontic or Orthopedic treatment is the indicated option to solve these problems; placement of fixed appliances in mouth increases risk of enamel demineralization; the braces, archwires, ligatures and other orthodontic appliances complicate the use of conventional oral-hygiene measures.

It is important to identify the changes in the oral environment in patients undergoing orthodontic treatment with fixed appliances, because in some cases involving long treatment duration and the clinicians are committed to preserving the oral health of the patient.

\section{Particularities of the orthodontic treatment}

Malocclusion is the third place in the oral diseases, the occurrence of occlusal anomalies varies between 11 al 93\%; the complications that it brings could be: psychological derived from the alteration of the dentofacial aesthetics; oral function problems, including difficulties in the mobility of the jaw, pain or disorders in the temporomandibular joint and problems to chew, to swallow or to speak; and finally, problems of major susceptibility to traumatism, periodontal diseases or dental decay (Proffit, 2008; Sidlauskas \& Lopatiené, 2009).

The orthodontic treatment can correct orofacial alterations, which can influence the patient's psique and social integration of the same one. Importantly, the face, the smiles and the teeth are part of the first impression of another person (Trulsson et al., 2002).

The purpose of the orthodontic treatment is to move the tooth as efficiently as be possible with the minimum of adverse effects to the tooth and the support tissues.

The requirements before initiating an orthodontic treatment are:

- $\quad$ Enough bone support (generally two thirds of the length of the root).

- To be sure that the occlusion will be stabilized at the ending of the treatment.

- The patient must have good health. 
- The patient must be motivated and cooperator.

When placed fixed appliances, besides the brackets, the orthodontic technique use other attachments as: bands (actually preformed), wires, springs or buttons.

The length of orthodontic treatment with fixed appliances has approximately 13-15 months; nevertheless, factors so far linked to increased treatment duration include anatomy, malocclusion, direction growth, molar class, extractions, use of fixed appliances in both arches, and others (Turbill et al., 2001).

Patients who undergo orthodontic therapy have oral ecologic changes because increased retentive sites for retention of food particles, which allows the bacterial growth.

Lesions developed during orthodontic treatment could be radicular resorption, gingival recession and increase of caries risk and periodontal diseases. The enamel decalcification is one of the most common and undesirable complications of the orthodontic therapy. Some authors (Chang et al., 1999; Heintze, 1999; Zárate et al., 2004) show increase of decalcifications or white spot lesions in patient on treatment.

Demineralization of the enamel around brackets can be an extremely rapid process, which appears most frequently on the cervical and middle thirds of the buccal surfaces of the maxillary lateral incisors, mandible canines and the first premolars. The prevalence of new enamel lesions in orthodontic patients treated with fixed appliances and using fluoride toothpaste is reported to be 13 to $75 \%$ (Derks et al., 2007).

We can find periodontal alterations after orthodontic treatment such as: generalized gingivitis after bonding and light lost of alveolar bone level and of epithelial insertion (Bollen et al., 2008).

It seems, that the bone lost could be more serious when more complex and extensive will be the orthodontic movement.

That is the reason because the maintenance of an effective oral hygiene is critical during the treatment.

We can considerate the next preventive measures in orthodontic patients:

- To evaluate the toothbrushing technique.

- To avoid the cariogenic diet.

- To evaluate the periodontal conditions during the treatment.

- To establish a continuos motivation for the oral care.

When we do a good orthodontic treatment and with a correct regime of oral hygiene, we do not have important periodontal complications.

It has been demonstrated that children who receive orthodontic therapy, at the end of this treatment, presents lower dental plaque levels and gingival bleeding that children who did not receive treatment; it could be because they have better dental alignment, but also to that the subjects modify his oral personal hygiene and attitude (Gwinnett \& Ceen, 1979).

\section{Caries risk markers on the orthodontic treatment}

Diagnostic tests may serve multiple clinical objectives that benefit the individual patient. The clinician may use tests to: a) identify predisposing risk factors to modify risk and 
prevent disease; b) identify early disease-associated biochemical or physical changes prior to clinical signs of disease to halt the changes and reverse damage prior to loss of function; and c) determine which specific type of disease is involved to guide selection of the most effective therapy (Kornman, 2005; Sánchez \& Sáenz, 2003).

Risk markers are biologic markers that either indicate disease or disease progression but are not causal or represent historical evidence of the disease, risk factors are characteristics of the person or environment that, when present, directly result in an increased likelihood that a person will get a disease and, when absent, directly result in a decreased likelihood of disease.

Risk factors for prediction of caries activity have been described by Featherstone (2000) and involve a balance between well-described pathological and protective factors. The pathological factors are primarily the levels of acidogenic bacteria, the frequency of fermentable carbohydrate ingestion, and the level of saliva flow. The protective factors include salivary proteins and antibacterial components, salivary composition of key minerals-for example, calcium and fluoride-and protective dietary components (Kornman, 2005; Featherstone, 2000).

About caries risk factors that it must be valued we can mention the following ones:

\subsection{Clinical markers}

To be able to evaluate the caries risk exist different markers, principally DMFT or DMFS index and bacterial counts (Streptococci mutans and Lactobacillus). The historical experience to caries that the patient presents by the DMFT or DMFS index is one of the most powerful predictor to caries risk. Nevertheless, it is well know that the caries is multifactorial and can change from a population to other one, from an individual to other one even from a group of teeth to other one.

\subsubsection{DMFS index}

The DMFT index was developed by Klein, Palmer and Knutson during a study of the dental condition and the need of children's treatment in elementary schools in Hagerstown, Maryland, USA, in 1935. It has been the most important index in the dental researches to quantify the prevalence of tooth decay (Katz et.al., 1997).

The caries experience (past and present) indicates the teeth damages and treatments received before by the count of teeth decays or natural history of the dental caries, which it expresses as decayed, missing and filled teeth (DMFT index) or decayed, missing and filled surfaces (DMFS index), both indexes express numerically the caries prevalence. The sum of these three points is the index (Sánchez \& Sáenz, 1998; World Health Organization [WHO], 1997; WHO, 2011b).

For better analysis and interpretation it will be separate in each component and express it by percentage or mean. This is important to compare populations.

To obtain DMFT index in population, WHO recommended the next age groups: 5-6, 12, 15, $18,35-44,60-74$ years. The index at 12 age is used to compare the oral health between countries. 
The scientific evidences suggest that this is the most sensitive indicator to predict future risk, since if a subject does not establish the biochemical balance between demineralizationremineralization it will develop more caries lesions.

World Health Organization clearly established the methodology to obtain the index in the Oral Health Surveys. As increase the lesions number, increases the risk to develop caries, even in filled teeth (WHO, 1997).

The subjects are examined in the clinic area with the aid of a dental mouth mirror and periodontal probe, type $\mathrm{E}$. The presence of caries was recorded using WHO's DMFS criteria.

For permanent dentition use the next codes:

\begin{tabular}{cc} 
Codes & Condicion \\
\hline 0 & Health \\
1 & Decayed \\
2 & Filled with caries \\
3 & Filled without caries \\
4 & Missing by caries \\
5 & Missing by other reason \\
6 & Sealant, coat \\
7 & Bridge or crown \\
8 & Non eruption \\
9 & Exclude
\end{tabular}

0: showing no evidence of either treated or untreated caries. A crown may have defects and still be recorded as 0 . Defects that can be disregarded include white spots; discolored or rough spots that are not soft; stained enamel pits or fissures; dark, shiny, hard, pitted areas of moderate to severe fluorosis; or abraded areas.

1: indicates a tooth with caries. A tooth or root with a definite cavity, undermined enamel, or detectably softened or leathery area of enamel or cementum can be designated a 1 . A tooth with a temporary filling, and teeth that are sealed but decayed, are also termed 1.

2: Filled teeth, with additional decay. No distinction is made between primary caries which is not associated with a previous filling, and secondary caries, adjacent to an existing restoration.

3: indicates a filled tooth with no decay. If a tooth has been crowned because of previous decay, that tooth is judged a 3 . When a tooth has been crowned for another reason such as aesthetics or for use as a bridge abutment, a 7 is used.

4: indicates a tooth that is missing as a result of caries. When primary teeth are missing, the score should be used only if the tooth is missing prematurely. Primary teeth missing because of normal exfoliation need no recording.

5: a permanent tooth missing for any other reason than decay is given a 5. Examples are teeth extracted for orthodontics or periodontal disease, teeth that are congenitally missing, or teeth missing by trauma. 
6: is assigned to teeth on which sealants have been placed. Teeth on which the occlusal fissure has been enlarged and a composite material placed should also be termed 6 .

7: is used to indicate that the tooth is part of a fixed bridge. When a tooth has been crowned for a reason other than decay, this code is also used. Teeth that have veneers or laminates covering the facial surface are also termed 7 when there is no evidence of caries or restoration. A 7 is also used to indicate a root replaced by an implant. Teeth that have been replaced by bridge pontics are scored 4 or 5 ; their roots are scored 9 .

8: this code is used for a space with an unerupted permanent tooth where no primary tooth is present. The category does not include missing teeth.

9: Erupted teeth that cannot be examined-because of orthodontic bands, for example-are scored a 9.

The "D" of DMFT refers to all teeth with codes 1 and 2. The "M" applies to teeth scored 4 in subjects under age 30 , and teeth scored 4 or 5 in subjects over age 30 . The "F" refers to teeth with code 3 . Those teeth coded 6, 7, 8, 9, or T are not included in DMFT calculations.

The parameters to reference are:

Low $\quad 1$ to 3 caries lesions

Moderate $\quad 4$ to 6 caries lesions

High $\quad 7$ to 9 caries lesions

Higher $\quad 10$ or mores caries lesions (Fig. 1).

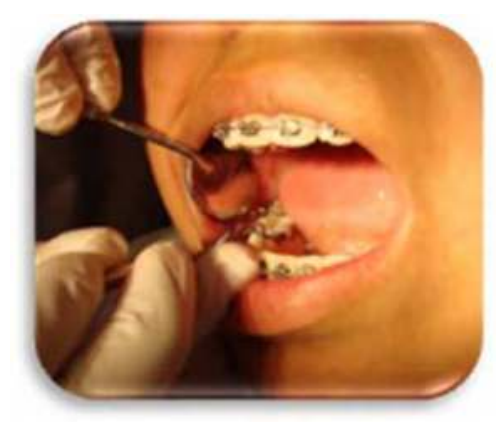

Fig. 1. Obtained DMFS index.

\subsubsection{Supragingival plaque}

The dental plaque represents a bacterial structure formed in the surfaces of the teeth that cannot be eliminated by water, which contains great number of microorganisms grouped and surrounded with extracellular materials from bacterial and salivary origin.

It has two phases related between them: inner one, with the enamel, where they find salivary free components of cells forming a cuticle or cap named biofilm and another in contact with the oral cavity, named interface plaque - saliva. If a tooth is cleaned deeply, exposing the enamel to the oral environment, in less than one hour this one would remain covered by the biofilm, whereas the initial formation of the dental plaque can need up to two hours. (Harris \& García-Godoy, 2001; Menaker et al., 1986) 
The principal diseases originated by dental plaque are caries and periodontal diseases, they originate in sites where the dental plaque is more abundant and is stagnant.

A number of plaque indices have been developed for assessing individual levels of plaque control and are also have been used in several epidemiological studies. Some of the most well - known indices, which have been used in numerous studies, are listed below:

- $\quad$ Oral Hygiene Index (Greene and Vermillion, 1960)

- $\quad$ Simplified Oral Hygiene Index (OHI-S, Greene and Vermillion, 1964)

- $\quad$ Silness-Löe Index (Silness and Löe, 1964)

- $\quad$ Quigley Hein Index (Modified by Turesky et al, 1970)

- $\quad$ The Plaque Control Record (O' Leary T, Drake R, Naylor, 1972).

The plaque control record evaluating the presence of soft debris on the tooth surfaces and dentogingival junction, as well as toothbrushing efficacy. (Butler et al., 1996; O'Leary et al., 1972).

According to $\mathrm{O}^{\prime}$ Leary index, plaque is disclosed with a chewable tablet and its amount estimated. To determine an individual's score, the clinician multiplies the number of surfaces with plaque by 100, and divides that by the number of tooth surfaces examined. (WHO, 2011a) (Fig. 2).
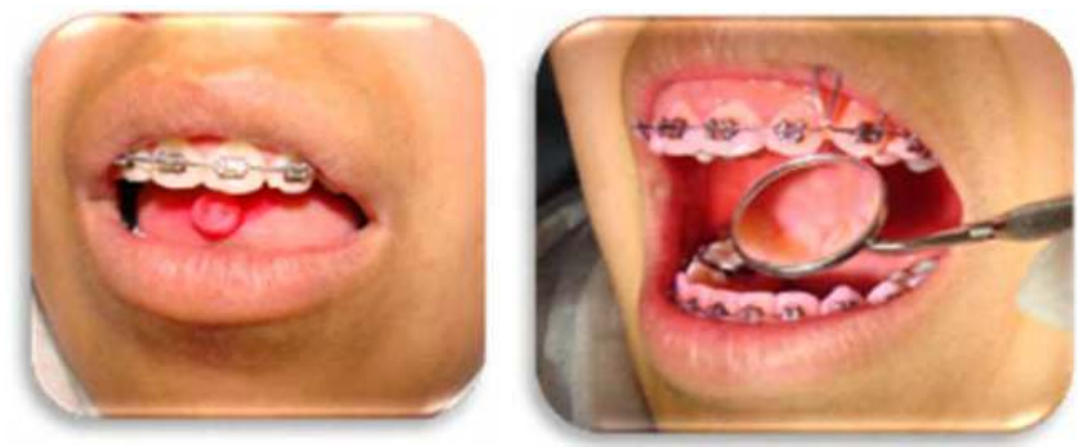

Fig. 2. Plaque control record.

\subsection{Salivary markers}

Saliva is a fluid present in mouth that comes from major and minor glands. Saliva is essential for the protection of the tooth against dental caries and protects the integrity of the soft oral tissues, facilitates the mastication, the swallowing and the speech, as well as the sensibility and the digestive functions in the oral cavity. Near $99 \%$ of saliva is water, $1 \%$ remaining consists of a complex mixture of constituent to different concentrations (Harris \& García Godoy, 2001; Featherstone, 2000; Fenoll-Palomares et al., 2004; Larmas, 1992; Leone, 2001).

The principal functions of the saliva are:

1. Protection functions (lubrication, preserve the integrity of the oral mucous, cleanliness, buffer capacity, dental remineralization and antimicrobial). 
2. Functions related to the mastication and the speech (food preparation by the digestion, flavor and phonation) (Kaufman \& Lamster, 2000).

To evaluate the quantity of production as well as his functions helps us to determine factors of the guest in the development of dental decay.

\subsubsection{Unstimulated saliva}

The average of total saliva flow is 0.3 to $0.4 \mathrm{ml} / \mathrm{min}$ in adults, exist approximately a saliva secretion of $1500 \mathrm{ml} / 24 \mathrm{hrs}$. This rate of unstimulated saliva flow is based to a circadian rhythm, with a major flow in the middle of the evening and minor about 4 a.m. The flow changes considerably in persons who are resting. During sleep, the flow is very low or nonexistent and increases during the day, especially with the food ingestion.

An unstimulated salivary $<0.30 \mathrm{~mL} / \mathrm{min}$ it is considered like risk factor (Ansai et al., 1994; Harris \& García-Godoy, 2001; Fenoll-Palomares et al., 2004; Larmas, 1992; Leone, 2001; Zárate et al., 2004).

All salivary components neutralize the acids produced by cariogenic bacterias. For this reason the saliva production is important to support the oral health. Any agent or condition that reduces the quantity of saliva increases the risk of dental decay.

One way to measure this is by the formation time (in seconds) of small saliva drops in the inner mucous of the lower lip and compared with a chart. (Saliva Check ${ }^{\circledR 1}$ ) (Varma et al., 2008) (Fig. 3)

$\begin{array}{ll}\text { Low } & \text { greater than } 60 \text { seconds } \\ \text { Normal } & 30 \text { a } 60 \text { seconds } \\ \text { High } & \text { less than30 seconds }\end{array}$
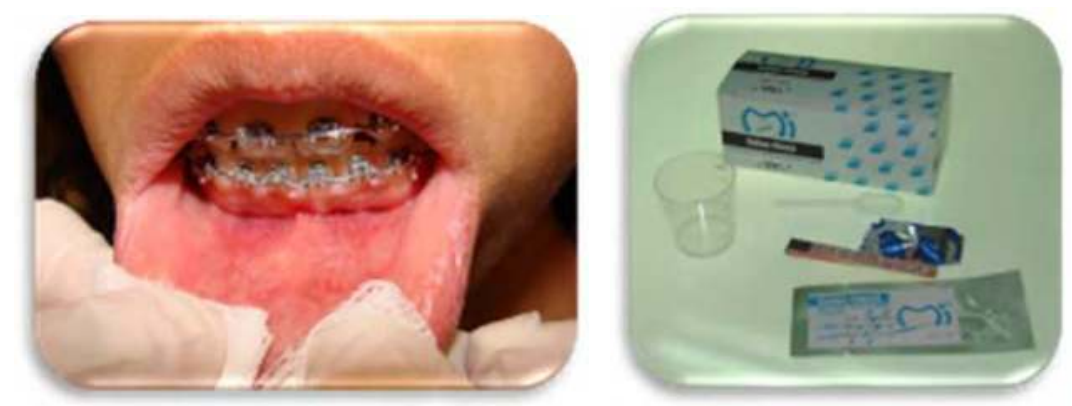

Fig. 3. Unstimulated saliva flow measured by Kit Saliva Check.

\subsubsection{Stimulated saliva}

Physiologically the stimulus can be mechanic as mastication. It can be gustatory as result of the stimulation of the gustatory or psychological papilla on having imagined the favorite food. Inversely, it can diminish with fear, radiation causing destruction of the salivary

1 Saliva Check ${ }^{\circledR}$, GC America Inc., Alsip, IL, USA. 
glands, thyroid insufficiency, Sjögren's syndrome or medicaments (neuroleptics, antidepressants and antihypertensives) (Harris \& García-Godoy, 2001) (Fig. 4)
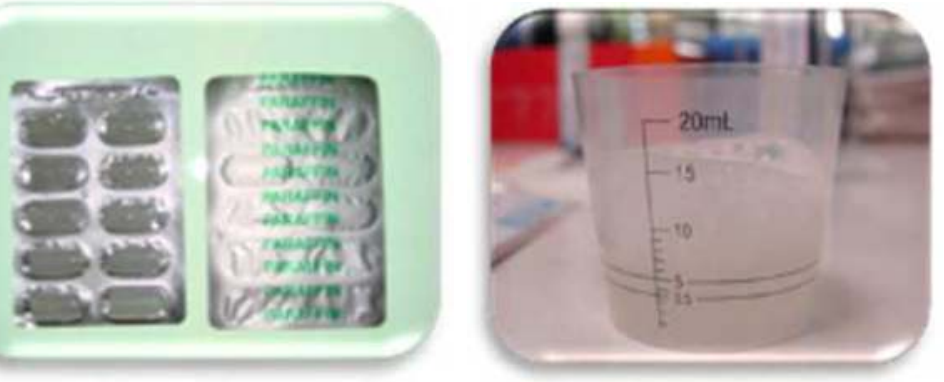

Fig. 4. Stimulated salivary flow.

Stimulated saliva could be obtained during 5 minutes by chewing an unflavored piece of wax or chewing gum; the result was expressed in $\mathrm{mL} / \mathrm{min}$. With a moderate stimulation, it can collect 1 to $2 \mathrm{~mL} / \mathrm{min}$. When the stimulated salivary flow is lower than $0.7 \mathrm{ml} / \mathrm{min}$, it could be xerostomia with a caries risk (Harris \& García-Godoy, 2001; Heintze et al., 1999).

\subsubsection{Salivary $\mathrm{pH}$}

Salivary $\mathrm{pH}$ is the acidity or alcalinity of the saliva, normally presents a $\mathrm{pH}$ of 6.3 , but could be modified by the oral health (Prieto \& Yuste, 2010).

If salivary $\mathrm{pH}$ diminished can increase the enamel demineralization. There is no exist an exact $\mathrm{pH}$ at which demineralization begins, it may be in the range of 5.5 to 5.0 (critical $\mathrm{pH}$ ). This is a very large range due to the mineralization is given according to $\mathrm{pH}$ and duration of exposure of the enamel surface to the acid environment (Anderson et al., 2001; Dawes, 2003).

The concept of critical $\mathrm{pH}$ is applicable only to solutions that are in contact with a particular mineral, such as enamel. Saliva and plaque fluid, for instance, are normally supersaturated with respect to tooth enamel because the $\mathrm{pH}$ is higher tan the critical $\mathrm{pH}$, so our teeth do not dissolve in our saliva or under plaque (Featherstone, 2000; Dawes, 2003) (Fig. 5).
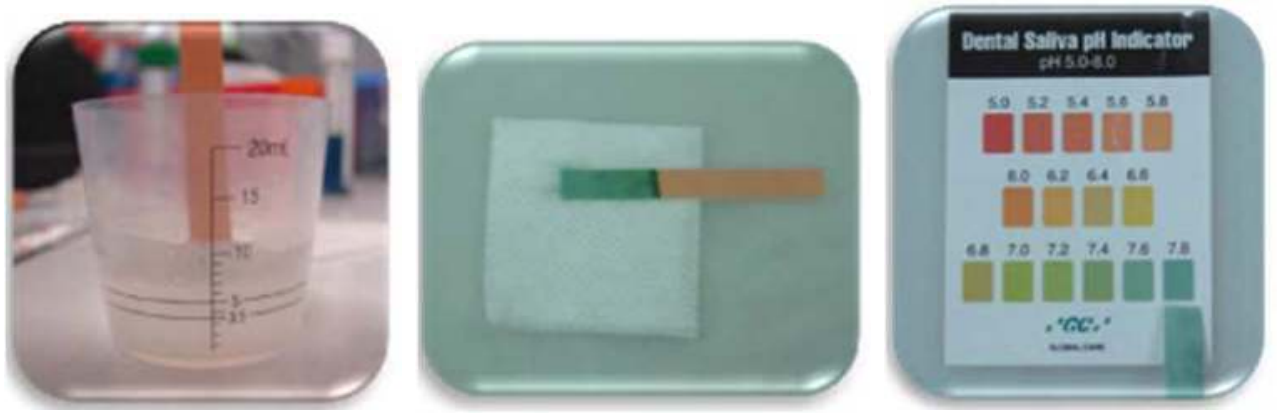

Fig. 5. The reactive strip comparate with the manufactured chart. 
To determine salivary $\mathrm{pH}$, you can use a ph-meter or by the reactive strip.

The Saliva Check ${ }^{\circledR 1}$ reactive strip is submerged in stimulated saliva for 10 to 20 seconds and the color obtained is compared with categorical levels in the chart:

Highly acidic

Moderately acidic

Healthy saliva red section ( $\mathrm{pH}$ de 5.0 to 5.8 )

yellow section ( $\mathrm{pH}$ de 6.0 to 6.6 )

green section ( $\mathrm{pH}$ de 6.8 to 7.8$)$.

\subsubsection{Buffer capacity}

Buffer capacity is the saliva ability to neutralize acids, salivary $\mathrm{pH}$ back to normal parameters after bacterial acidogenesis. After exposure to fermentable carbohydrate occur a series of reactions with decreasing $\mathrm{pH}$, as it decreases, some salivary minerals and proteins are liberate to avoid the salivary $\mathrm{pH}$ drop. Increased salivary buffering minimizes the final products of the acidogenic bacteria. Magnesium and carbonate ions are adsorbed to the enamel crystals, and then they are dissolved and added to the oral environment. Even calcium and phosphate ions are available for remineralization when the $\mathrm{pH}$ begins to return to normal parameters.

If acid production continues after 30 to 45 minutes, the $\mathrm{pH}$ rises and minerals in ionic form incorporate into the tooth structure. At this time reverse the demineralization process (Monterde et al., 2001).

This salivary function is one of the best indicators of caries susceptibility because it reveals the host response. Patients with high buffering capacity are resistant to the caries process. The low capacity may indicate: decreased salivary flow, reduced host response to cariogenic agents, possible malnutrition or pregnancy (Larmas, 1992).

Buffer capacity might be determined quickly placing stimulated saliva using a pipette in the reactive strip of the Saliva Check ${ }^{\circledR 1}$ test and will be compared with the chart after 2 minutes; the final result was obtained by adding the scores of 3 reactive zones:

$\begin{array}{ll}\text { Green } & 4 \text { points } \\ \text { Green/blue } & 3 \text { points } \\ \text { Blue } & 2 \text { points } \\ \text { Red/blue } & 1 \text { point } \\ \text { Red } & 0 \text { points (Fig. 6). }\end{array}$
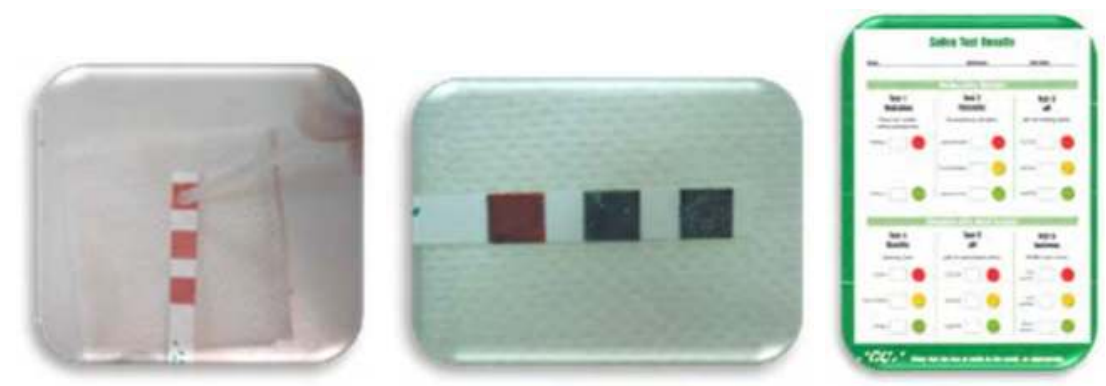

Fig. 6. Buffering capacity (Saliva Check $^{\circledR}$ ). 
Interpreting the result:

$\begin{array}{ll}\text { Very low } & 0 \text { to } 5 \text { points } \\ \text { Low } & 6 \text { to } 9 \text { points } \\ \text { Normal/High } & 10 \text { to } 12 \text { points }\end{array}$

\subsection{Bacterial markers}

The acids produced by bacterial fermentation in plaque dissolve the mineral matrix of the tooth. A reversible chalk-white spot is the first manifestation of the carious lesion, which can lead to cavitation if the mineral continues to be exposed to acid. Early detection of carious lesions provides a great opportunity to limit enamel demineralization associated with this process.

\subsubsection{Streptococus mutans}

Streptococcus mutans are bacterias that grow in chains or in pairs, no movement, non-spore forming and usually react positively to Gram test. The name given by the tendency to change shape, can be found as spheres or more elongated, like bacillus.

There are numerous reports of a positive correlation between the presence of mutans streptococci and caries increase (Ansai et al., 1994; Heintze et al., 1999; Larmas, 1992; Niwa \& Fukuda, 1989; Tanzer et al., 2001).

Streptococcus mutans are the most important bacterias at the beginning of the caries, colonize the host only after the first tooth erupts, are acquired primarily by direct transmission from mothers, have a preference for the occlusal surfaces of molars and interproximal areas of teeth and lack of ability to adhere to the oral soft tissues (National Institutes of Health Consensus, 2001).

The action of Streptococcus mutans, occurs in three phases: 1) initial interaction with the tooth surface via adhesins, 2) the colonization and growth of cariogenic bacteria in the film and 3) the production of glucose and glucans by the bacterial enzyme glucosyltransferase, which is involved into formation of lactic acid and initiates the process of demineralization of the tooth (Anusavice, 2005).

Microorganisms are more involved in the formation of cavities by their own virulence factors: acidogenicity, aciduric (acid produced in a medium with low $\mathrm{pH}$ ) and acidophilus (resists the acidity of the medium).

Diverse tests based predominantly on quantitative estimation of Streptococcus mutans per milliliter of saliva (colony-forming unit $[\mathrm{CFU}] / \mathrm{mL}$ ): MSBB method (Matsukubo et al.), Caries Screen SM (Jordan et al.) and Dentocult ${ }^{\circledR}$ SM (Orion Diagnostica, Espoo, Finland) according to Jensen and Bratthall (1989).

These three are based on the fact that bacitracin inhibits the growth of other oral streptococci except mutans on mitis salivarius medium (Fig. 7).

A recently developed Streptococcus mutans detection system, Saliva-Check SM® (GC America, USA), eliminates the need for an incubation period. It can detect salivary S. mutans levels in 30 minutes. 

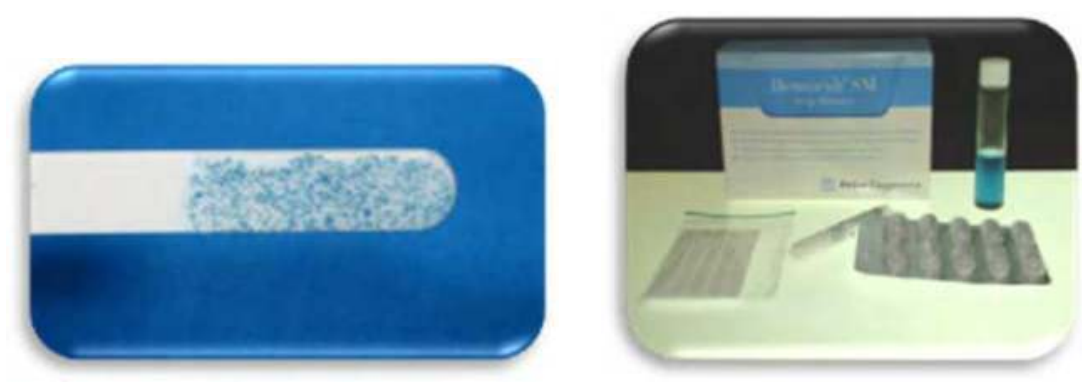

Fig. 7. Dentocult $S M ®$ strip mutans.

The average value for any possibility of decay should be more than 250,000 colony-forming unit (CFU) per milliliter of saliva, the higher values of 1'000, $000 \mathrm{CFU} / \mathrm{mL}$ indicate a high risk of caries (Heintze et al., 1999).

The bacitracin disc may be placed in the selective culture Dentocult ${ }^{\circledR} \mathrm{SM}^{2} ; 15$ minutes before sampling. Let the patient chew a paraffin pellet for 1 minute. This stimulates the secretion of saliva and transfers mutans streptococci from toothsurfaces into the saliva. Press the rough surface of the strip against the saliva remaining on the patient's tongue (Fig. 8).

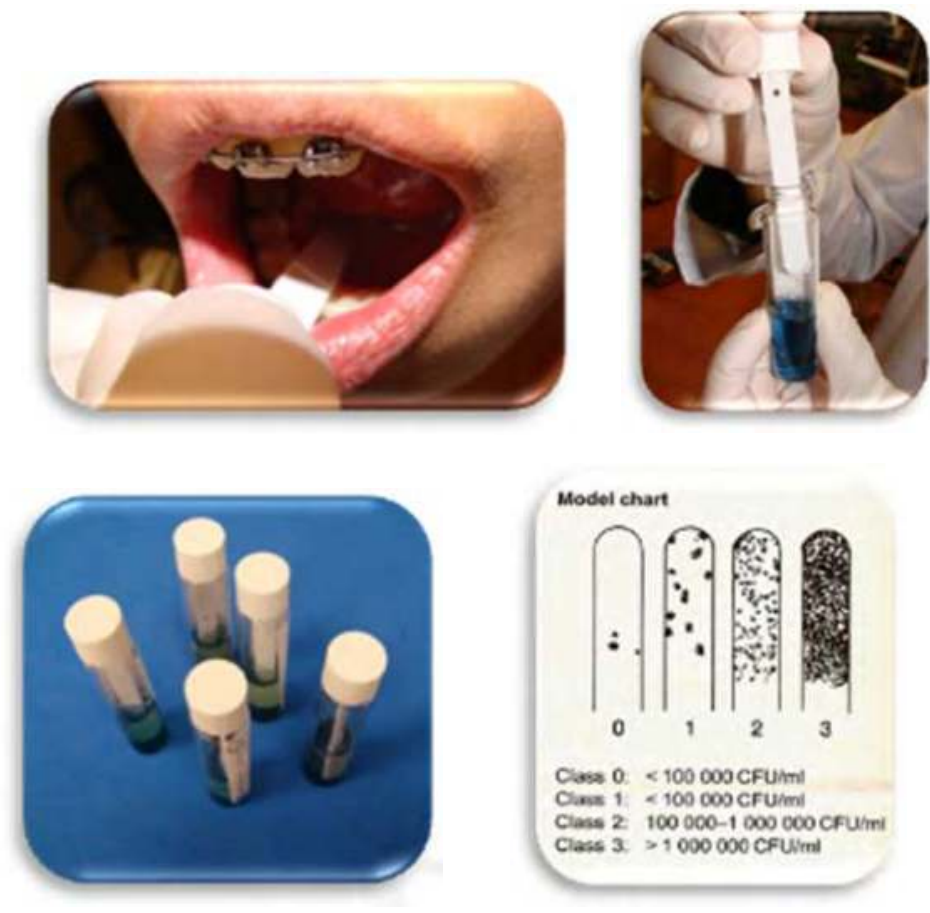

Fig. 8. Specimen collection, and model chart.

2 Dentocult@ SM Strip Mutans (Orion Diagnostica, Helsinki, Finland) 
Incubate the vial at $37^{\circ} \mathrm{C}$ for 48 hours with the cap one quarter of a turn open. Interpretation of results according following score:

0 negative or $<100000 \mathrm{CFU} / \mathrm{mL}$,

$1 \quad 100000$ to $1000000 \mathrm{CFU} / \mathrm{mL}$,

$210^{5}$ to $10^{6} \mathrm{CFU} / \mathrm{mL}$,

$3>1000000 \mathrm{CFU} / \mathrm{mL}$

\subsubsection{Lactobacillus}

Lactobacillus is considered secondary invaders, can contribute to tooth demineralization once they are established carious lesions. Lactobacilli can be found in the mouth before the teeth erupt, even when the diet is rich in fermentable carbohydrates and no active carious lesions.

They are present in small numbers on the plaque and tend to be found in saliva and in deep carious lesions. Weakly bind to the enamel surfaces, are lazy in their nutritional requirements, are acidogenic and aciduric. They are located in the undercut areas of the tooth, such as defects or margins of fillings or orthodontic bands (Ansai et al., 1994; Heintze et al., 1999; Menaker et al., 1986; Tanzer et al., 2001).

The development of caries should be considered in two-stage process: in Streptococcus mutans involved in lesion initiation and lactobacilli in progression it.

The standard method for determining the presence of lactobacilli is through the selective medium Rogosa SL agar. An alternative was established by Larmas in 1975 with the introduction of the test Dentocult LB®. The advantage is that it can be used in the dental office and the results can be shown to make the patient aware of the presence of lactobacilli in the mouth (Fig. 9).
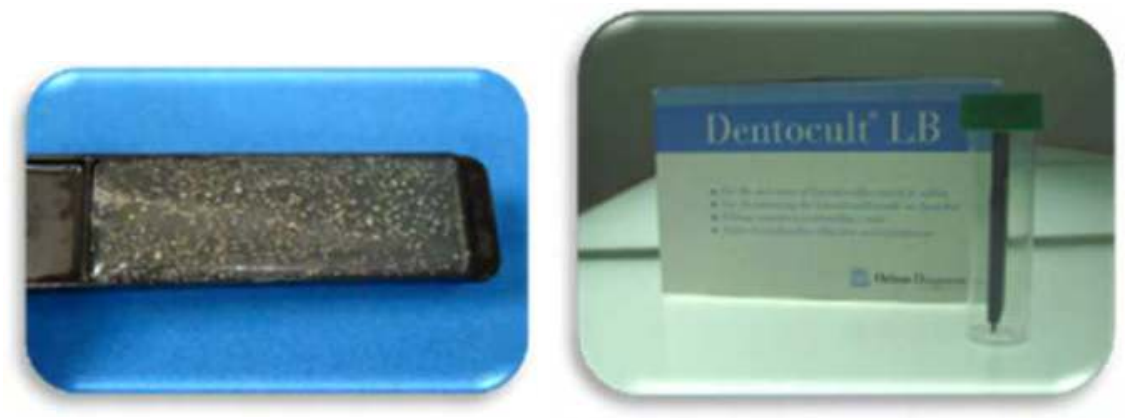

Fig. 9. Dentocult LB® test.

Values greater than 100,000 CFU / mL indicate a high risk of caries (Heintze et al., 1999; Larmas, 1992).

Dentocult ${ }^{\circledR}$ LB $^{3}$ procedure (Fig. 10) consists in pour the collected saliva over both agar surfaces, ensuring that they are well moistened. If the saliva is very viscous, the sample can also be applied using a sterile swab, then screw the slide tightly back into the tube and place

${ }^{3}$ Dentocult® LB (Orion Diagnostica, Helsinki, Finland) 
the tube in an incubator for 72 hours at $37^{\circ} \mathrm{C}$. To obtain a colony count remove the slide from the tube and compare the colony density with the model chart provided in the kit:

NC Non count or few colonies

$01000 \mathrm{UFC} / \mathrm{ml}$ (low)

$110000 \mathrm{UFC} / \mathrm{ml}$ (medium)

$2100000 \mathrm{UFC} / \mathrm{ml}$ (high)

$31000000 \mathrm{UFC} / \mathrm{ml}$ (higher)

Actually exists the CRT bacteria test (Ivoclar Vivadent AG, Schaan, Liechtenstein) which allows clearly identify and semi-quantitatively determine both cariogenic bacterias.

Prognosis of caries becomes more effective when the lactobacilli and streptococci tests are combined.
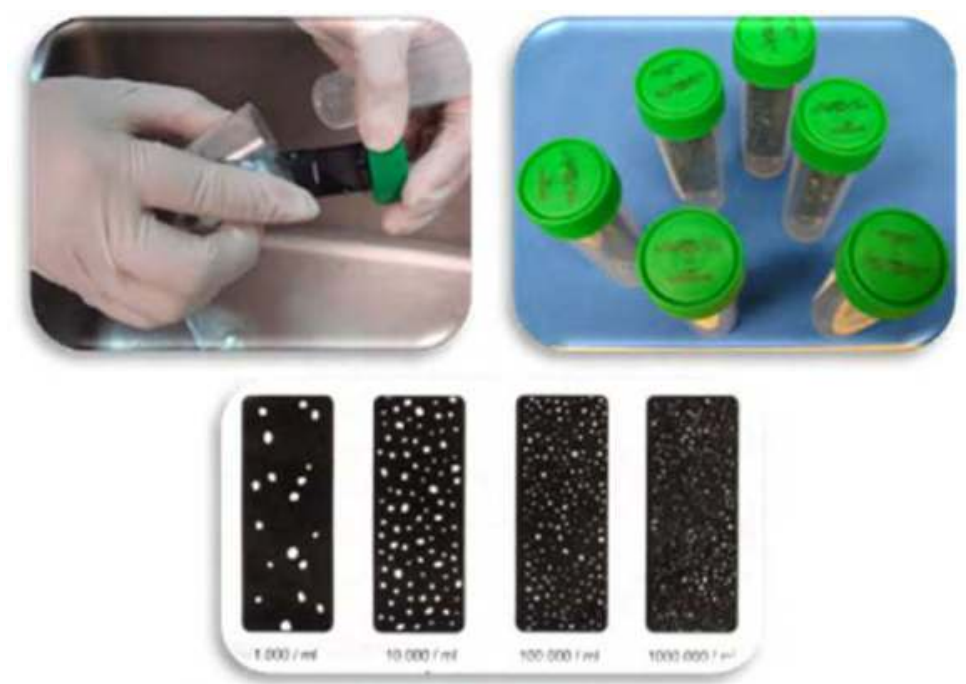

Fig. 10. Collect the lactobacillus sample, manufactured chart.

\subsection{Plaque pH}

Acidogenic bacteria in dental plaque metabolize carbohydrates rapidly getting acid as final product. The result is a change in $\mathrm{pH}$ of the plaque, as it relates to the time called the Stephan curve as a scheme to bring it takes a curve. The $\mathrm{pH}$ decreases rapidly in the first few minutes to gradually increase; it suggests that in 30 minutes should return to normal levels.

The caries activity test Cariostat ${ }^{\circledR 4}$, developed by Shimono, is used to measure the decrease of $\mathrm{pH}$ caused by bacterial action in the plaque. It has been reported positive correlations between caries activity test score and the counts of $S M$ and $L B$.

Not only can determine whether establishing new carious lesions, but also diagnose active or chronic lesions present (Nishimura et al., 1988; Lara-Carrillo et al., 2010b).

${ }^{4}$ Cariostat ${ }^{(D e n t s p l y-S a n k i n ~ K K, ~ T o k y o, ~ J a p a n) ~}$ 
Munshi et al. (1999) reported a Cariostat ${ }^{\circledR}$ sensitivity of $96.7 \%$ and a specificity of $93.3 \%$.

The procedure of Cariostat ${ }^{\circledR}$ is by changing color as a result of increased production of acids produced by fermentation of bacteria, is very sensitive and its relevance lies in its ability to predict the presence of caries in the future (Munshi et al., 1999).

It contains a high concentration of sucrose tryptose growth inhibitor of Gram-negative bacteria, with two types of indicators (green bromocresol and purple) to reveal visually the pH decrease in dental plaque (Ansai et al., 1994; Kornman, 2005; Nishimura et al., 1988a, 2008b).

A pH range of $4.0 \pm 3$ is considered high risk or marked caries activity.

Plaque is collected from buccal surfaces of first upper molars, using a sterilized cotton swab supplied in the kit, which was put into a test medium and incubated 48 hours at $37^{\circ} \mathrm{C}$. The test color change is compared with the pattern provided by the manufacturer as follows:

Blue

Green $\quad$ one positive value $=\mathrm{pH} 5.4 \pm 0.3$

Yellow greenish two positives value $=\mathrm{pH} 4.8 \pm 0.3$

Yellow three positives value $=\mathrm{pH}<\overline{4} .4$ (Fig. 11).

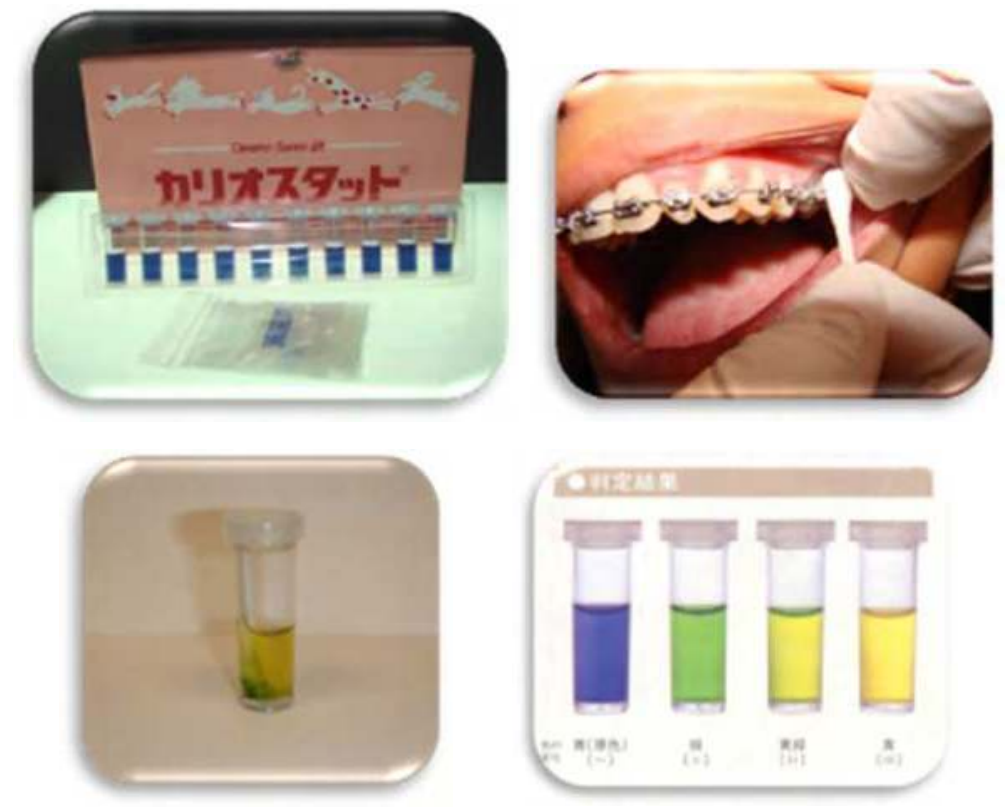

Fig. 11. Caries activity test Cariostat ${ }^{\circledR}$.

\subsection{Occult blood in saliva}

The use of saliva for periodontal diagnosis has been subject to several investigations, which have been proposed for disease markers including proteins, cells, hormones, volatile components, ions, bacteria and bacterial products, among others. 
It has become the leukocytes counts, in these salivary markers as an indicator of periodontal disease, since most of the salivary leukocytes entering to the oral cavity through the crevicular fluid when exist gingival inflammation, but these cells vary from person to person and even in one person can change during the day (Kaufman \& Lamster, 2000).

Actually exists another colorimetric salivary test used as indicator at inflammation which involves determining occult blood derived from the gingival tissue for evaluates periodontal disease in initial stages, called Salivaster ${ }^{\circledR 5}$ (Hashimoto et al., 2006; Niwa, \& Fukuda, 1989).

The Salivaster ${ }^{\circledR}$ is a colorimetric test based on a catalytic reaction of hemoglobin in saliva inducing the formation of different colors ranging from yellow to dark green. The principle of the color reaction is similar to the test for blood in urine, but was developed for the particular viscosity of saliva (Fig. 12).

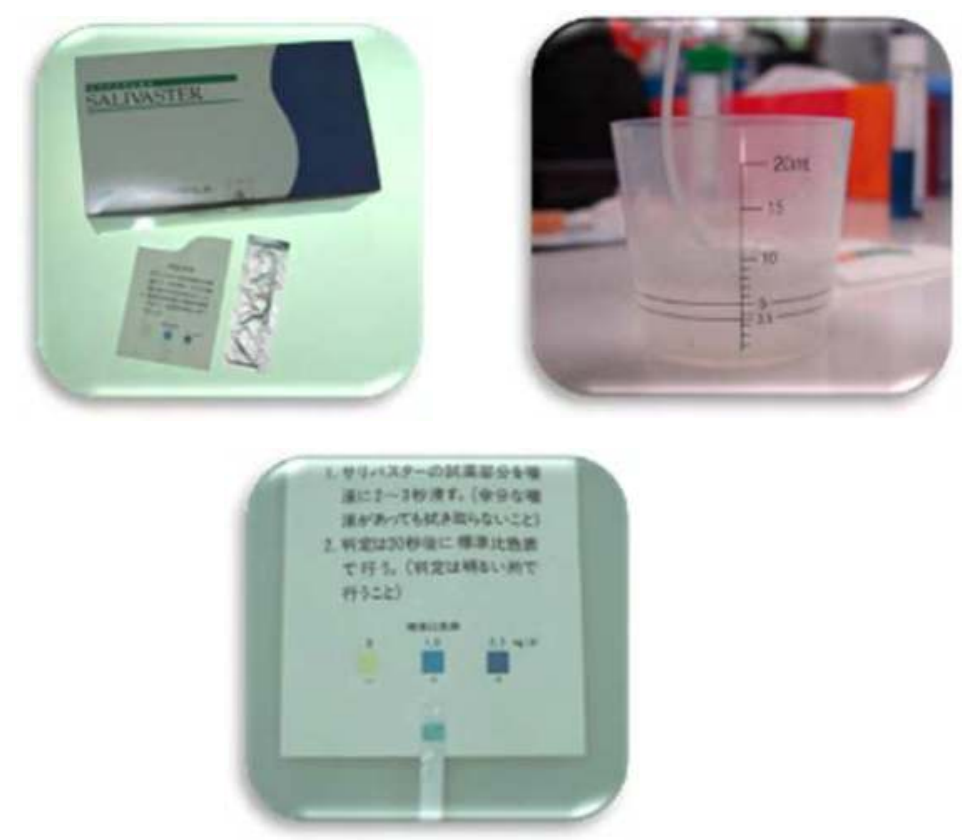

Fig. 12. Initial indicator of periodontal disease through occult blood in saliva (Salivaster $\left.{ }^{\circledR}\right)$

It is reported that this method has a sensitivity of $75.9 \%$ and a specificity of $90.5 \%$ for the detection of gingival inflammation (Kaufman \& Lamster, 2000).

The procedure involves dipping the test paper in stimulated saliva for 2-3 seconds and then judging by comparing to the standard color change chart, divided into 3 levels:

Yellow

$0.0 \mathrm{mg}$ of blood per $\mathrm{dL}$ of saliva (no periodontal disease)

Llight blue

$1.0 \mathrm{mg} / \mathrm{dL}$ (incipient periodontal disease)

Dark blue

$2.5 \mathrm{mg} / \mathrm{dL}$ (periodontal disease present).

${ }^{5}$ Salivaster ${ }^{(S h o w a ~ Y a k u h i n ~ K a k o ~ C o . ~ L T D, ~ T o k y o, ~ J a p a n) ~}$ 


\subsection{Hygienic-dietary habits}

This section covers those data on the frequency and quality of oral hygiene and consistency of diet, time and frequency of food intake.

There is little doubt that the change in lifestyle of civilization was resulting in an increase in the prevalence of dental caries, referring mainly to the increase of the diet of soft foods that contain carbohydrates.

Certain features of sugary foods and the conditions under which they are ingested, are more important in determining the cariogenic potential than amount of sugar (Moynihan, 2005).

The factors that establish the potential cariogenicity of sugary foods are:

- The physical consistency of the diet: food adhesives are more retentive than noncariogenic.

- Time of ingestion: sugary foods are more dangerous when consumed between meals, as the natural defense mechanisms operate at maximum during meals. The worst time to cariogenic food is just before bedtime, because the mouth is dry by the circadian rhythm of saliva during sleep.

- The frequency: sugar intake reduces the $\mathrm{pH}$ of dental plaque that facilitates demineralization and promotes tooth decay, so that the more frequent the intake, more cariogenic foods become.

The severity of the above is that the sugars are rapidly degraded by bacteria in acidic metabolic end products, which will result in a greater demineralization process than remineralization with subsequent carious lesions.

But also, there are certain foods that can protect against the formation of dental caries by the substances that they contain in their structure, either because they are fibrous, fatty or protein, etc. which reduces their cariogenic potential, and when mixed with sugary foods, reduce the potential of the latter, these are called protective foods, among which we mention the cheese. It has been shown to finish a meal with cheese for dessert, reduces the acidity of the plaque and therefore tooth decay (cariostatic).

The cheese prevents enamel demineralization by two different mechanisms: by stimulating the flow of saliva, which buffers the plaque and by increasing concentrations of calcium and phosphorus in dental plaque, which promotes remineralization (Saroglu, 2007).

In recent years, has also increased the use of sweeteners and sugar substitutes; investigations have focused mainly on sugar alcohols (sorbitol, mannitol, maltitol and xylitol), starch hydrolysates (Lycasin), protein (Monellina) and synthetic chemicals (saccharin, cyclamate and aspartic). Unlike sugar, these are poorly metabolized by oral bacteria or metabolized by pathways that lead to acid formation. Even some of them reduce the bacterial metabolism and consequently the development of plaque on the oral tissues. Nutrition education is very important, also correct oral hygiene with effective brushing after every meal is basically in oral health, while considering preventive periodic revisions to the dentist.

The useful life of a toothbrush is determined more by the brushing method that the length of use. Its half-life is approximately three months; however, this estimate may vary due to differences in the brushing habits. 
They have developed several methods of toothbrushing and most are identified by a single name like Bass, Stillman, Charters, or by a term indicating the main action to be taken: as spinning or massage.

The objectives of brushing are:

- $\quad$ Remove the plaque and stop the growth of it.

- Clean the teeth of food, debris and stains.

- Stimulate the gingival tissues.

Although the brush is the main mechanical means of plaque removal, often required of dental auxiliaries to remove residual plaque present in the proximal surfaces, among which include: dental floss, interdental cleaners, oral irrigators, mouth rinses buccal interdental sticks, and others (Klaus et al., 1991).

However, the majority of the population is disabled, unmotivated or are unaware of the need to devote time to remove the plaque from all tooth surfaces, or using products not suitable for removing plaque on the site crucial, or both.

To know the habits of the patient is recommended to apply a questionnaire which included a series of questions regarding daily brushing and eating habits, focusing on behavioral risk factors for dental disease. (Fig. 13).

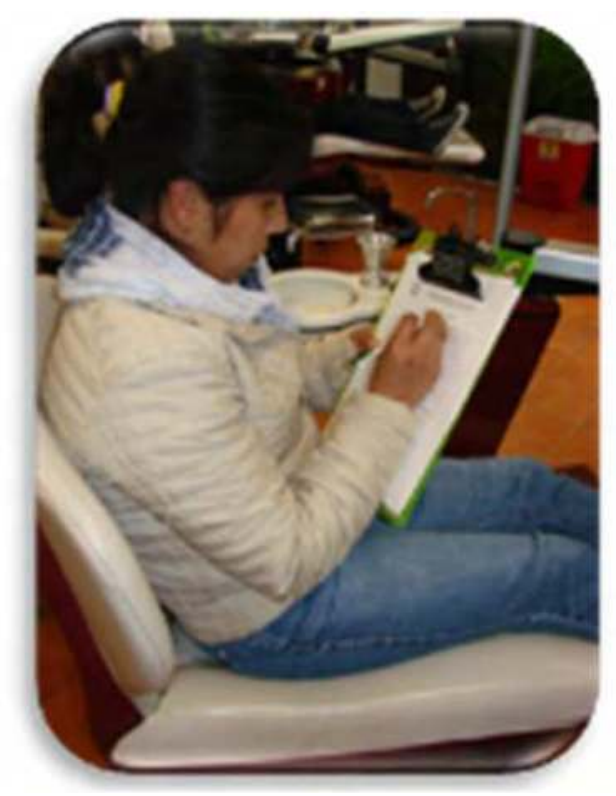

Fig. 13. Filling the questionnaire dietary and hygiene habits

\section{Collection of samples}

We recommended that patients brush their teeth three times a day using the Bass modified technique with toothpaste containing fluoride after placement of the appliances. 
Recommendations to avoid retentive, cariogenic, or hard foods during orthodontic treatment were provided verbally.

For take the tests is necessary that the patients avoided eating or drinking and no toothbrushing at least 2 hours before taking the samples in both time points.

In our experience, with thirty-four subjects, where 14 males (mean age, $16.2 \pm 3.4$ years) and 20 females (mean age, $17.2 \pm 6.3$ years), we selected patients didn't have any systemic diseases, use of antibiotics at least 15 days before initiating the study, active caries, and on mixed dentition phase were excluded.

Two samples were taken from each patient, one before beginning the orthodontic treatment and the other 1 month after placement of the appliances, because this is the time for the appointment to change the first arch wire. The orthodontics attachments were placed in both arches.

Dental and skeletal diagnoses were obtained from each patient, defined by Angle's molar class and the subspinale-nasion-supramentale cephalometric angle (ANB). Fifteen patients had molar relation class I, fourteen had class II, four had class III, and in one patient it was not possible to determine the relationship due to absent first molars.

As for the skeletal diagnosis, fourteen were class I, nineteen were class II, and one were class III. The dental and skeletal diagnoses were not associated or determined the behavior of any of the studied variables ( $p>0.05)$ (data not shown).

\subsection{Clinical markers}

The mean DMFS index of the subjects was 6.47, although it was greater in females (8.70) that in males (3.28), these differences were not statistically significant $(\mathrm{P}=0.1352$. The mean O’Leary's plaque index was $44.6 \%$, males presented a slightly plaque percentage $(50.84 \%)$ than females $(40.15 \%$; $\mathrm{P}=0.1809)$ (data not shown).

\subsection{Salivary markers}

We did not find a statistically significant difference in the unstimulated salivary production before and 1-month after the placement of orthodontic appliances, nevertheless according to time point, in both samples, there were differences between the saliva production of males and females $(P=0.0026)$; specifically, the unstimulated salivary production was lower in women (Table 1).

The placement of orthodontic appliances promoted a major stimulated salivary flow in the subjects, with significant differences in the salivary production before and after treatment $(P$ $=0.0001)$. The salivary stimulated flow rate was greater in males at the beginning $(P=$ 0.0019; Table 1). The salivary buffer capacity showed differences after placement of the appliances $(P=0.0359)$ and between genders before the treatment $(P=0.0381)$ females showed lower capacity (Table 1).

Significant differences were observed in the salivary $\mathrm{pH}$ before and after treatment $(P=$ 0.0246) with an increase of the $\mathrm{pH}$ value (Table 1 ). 


\begin{tabular}{llccr}
\multirow{2}{*}{ Marker } & Gender & \multicolumn{2}{c}{ Stages } & \multirow{2}{*}{ Pa } \\
\cline { 3 - 4 } Salivary markers & & Before & After & \\
Unstimulated saliva (seconds) & Male & $39.85 \pm 19.17$ & $38.64 \pm 14.90$ & \\
& Female & $45.65 \pm 19.03$ & $57.35 \pm 17.43$ & 0.4073 \\
& $\mathrm{p}^{\mathrm{b}}$ & 0.3903 & $0.0026^{*}$ & \\
Stimulated saliva (mL/min) & Male & $1.72 \pm 0.65$ & $1.76 \pm 0.80$ & \\
& Female & $1.06 \pm 0.48$ & $1.36 \pm 0.50$ & $0.0001^{*}$ \\
& $\mathrm{p}^{\mathrm{b}}$ & $0.0019^{*}$ & 0.0835 & \\
Buffer capacity & Male & $8.78 \pm 2.19$ & $8.71 \pm 2.16$ & \\
& Female & $6.90 \pm 2.69$ & $7.70 \pm 1.59$ & $0.0359^{*}$ \\
& $\mathrm{p}^{\mathrm{b}}$ & $0.0381^{*}$ & 0.1247 & \\
Salivary pH & Male & $7.68 \pm 0.17$ & $7.74 \pm 0.09$ & \\
& Female & $7.53 \pm 0.38$ & $7.73 \pm 0.09$ & $0.0246^{*}$ \\
& $\mathrm{p}^{\mathrm{b}}$ & 0.1672 & 0.7039 & \\
\hline
\end{tabular}

Data shown as mean \pm SD

$\mathrm{p}^{\mathrm{a}}$ value between before vs. after placement of appliances, based on paired t-test $\mathrm{p}^{\mathrm{b}}$ value between genders, based on paired $\mathrm{t}$-test ${ }^{*} \mathrm{P}<0.05$

Table 1. Distribution of salivary markers by gender in the study $(n=34)$

\subsection{Bacterial markers}

We observed changes in the CFU of SM after the placement of appliances. Before treatment $14 / 34$ subjects had high values (>105); after one month of banding, 16/34 had high values.

In the first sample $7 / 34$ subjects had high levels $\left(>10^{5}\right)$ of $L B$, for the second sample we found 20/34 subjects in these same level, although statistically significant differences were not observed in the bacterial counts distribution (Table 2).

\subsection{Plaque $\mathrm{pH}$}

The acidity of the initial plaque no registered significant modifications after the placement of appliances $(P=0.5467)$; however, we found differences between genders in the initial sample $(P=0.0430)$; the $\mathrm{pH}$ between 5.8-7.2 predominating in females, and lowest values (pH $5.4 \pm 0.3$ ) in males. The second sample showed more subjects with lowest values ( $\mathrm{pH} 5.4$ \pm 0.3 ) in both genders (Table 2).

\subsection{Occult blood in saliva}

Differences were observed in the gingival bleeding before and after orthodontic treatment $(P$ $=0.0305)$, with an increased the bleeding in saliva in the second sample. It has to be considered that in the beginning of the study most of the subjects were in the intermediate 
level with $1 \mathrm{mg} / \mathrm{dL}$ of occult blood in saliva (incipient periodontal disease) and one month later the periodontal disease present increase (Table 2).

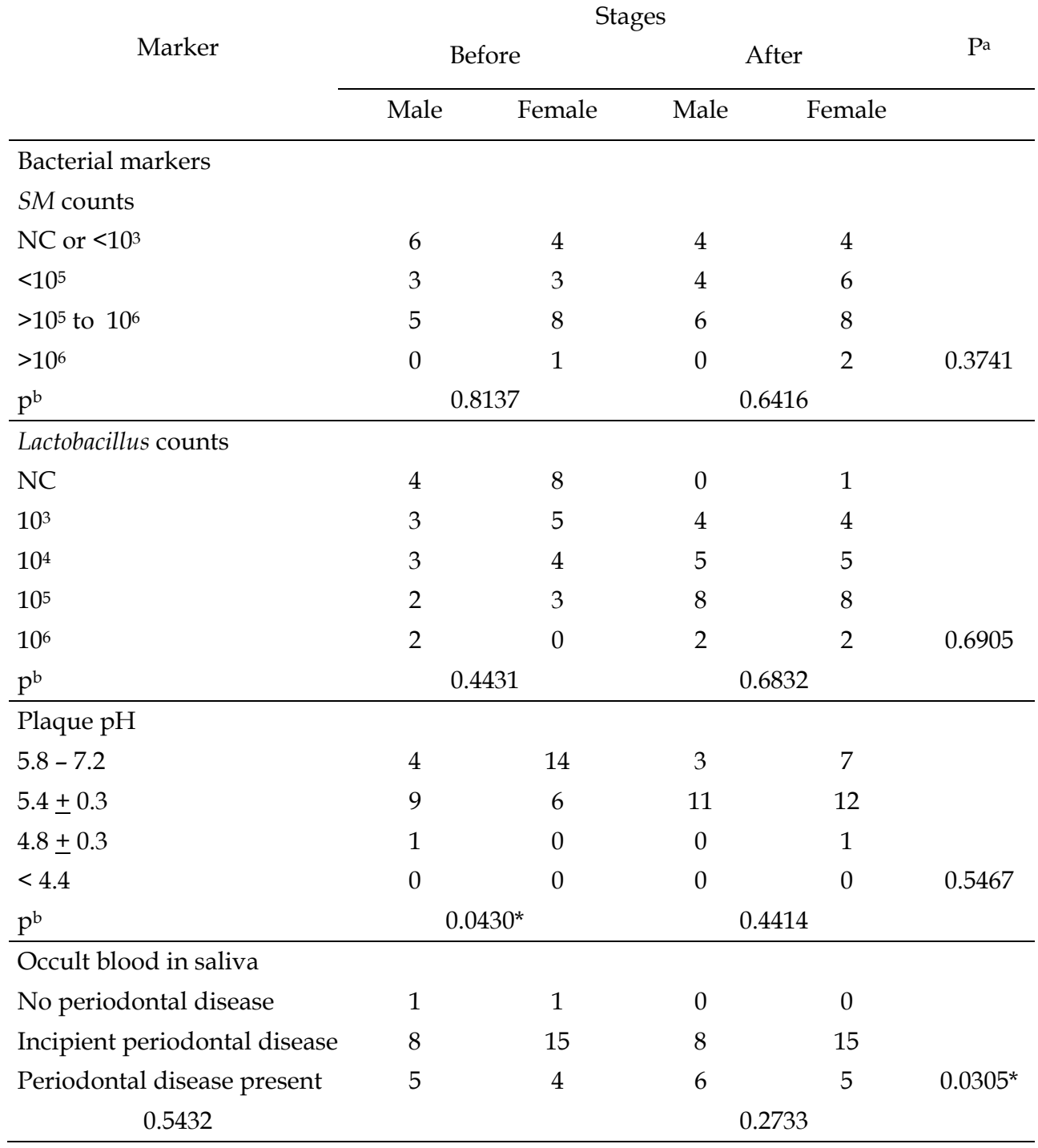

$\mathrm{NC}=$ negative at culture

$\mathrm{Pa}^{\mathrm{a}}$ value between before vs. after placement of appliances, based on $\mathrm{X}^{2}$ test

$\mathrm{Pb}^{\mathrm{b}}$ value between genders, based on $\mathrm{X}^{2}$ test

${ }^{*} \mathrm{P}<0.05$

Table 2. Distribution of bacterial markers, plaque $\mathrm{pH}$ and occult blood in saliva by gender in the study $(\mathrm{n}=34)$ 
It is established that orthodontic treatment induces changes in the oral environment, with increasing concentrations of mutans streptococci and lactobacilli, as well as increased blood concentration in saliva and decreased plaque $\mathrm{pH}$.

This is exacerbated in stages which increase the use of attachments and the consequent difficulty of proper hygiene.

\section{Conclusions}

The clinical markers showed that males had lower DMFS index than females, nevertheless, the plaque index by O'Leary showed more plaque in males of this study.

The stimulated salivary flow increased after the placement of orthodontic appliances. In the present study it was greater in males, which is similar to international reports (Chang et al., 1999; Bretz et al., 2001; De Vigna et al., 2008).

The mean salivary flow rate for both genders was found in normal parameters: $1-3 \mathrm{~mL} / \mathrm{min}$ in stimulated saliva and from $0.25-0.35 \mathrm{~mL} / \mathrm{min}$ in unstimulated saliva. The variability of salivary flow rate has been established by other researchers (Torres et al, 2006).

The results support a direct and prolonged stimulatory effect after one month of treatment with fixed orthodontic appliances on salivary flow.

The saliva buffer capacity presented a significant increase in females after the orthodontic therapy. Males showed higher buffer capacity than females, this difference between genders have been demonstrated previously.

The salivary buffer capacity prevents the settling of pathogenic microorganisms in mouth, being an important risk indicator, because it reveals the response of the host.

Salivary $\mathrm{pH}$ demonstrated a significant increase in the $1^{\text {st }}$ month of treatment, as opposed to other studies in which it has been demonstrated that the $\mathrm{pH}$ suffers alterations after 3 months of orthodontic treatment (Chang et al., 1999).

Males showed a more acid plaque $\mathrm{pH}$ at the beginning of the treatment, nevertheless an increase in acidity was demonstrated 1 month with orthodontic appliances in females. The plaque $\mathrm{pH}$ had significant differences between genders when the patients already were in orthodontic treatment.

The orthodontic appliances protected the plaque from the tooth brushing action, the mastication, and the salivary fluid. Accumulating more on the cervical region of the brackets or below the arches wire, which is the zone where a major demineralization can be found (Migale et al., 2009).

The present study showed an increase of CFU after placement of the orthodontic appliances, which has been demonstrated also by Chang (1999). Nevertheless, these changes in the $1^{\text {st }}$ month of study were not statistically significant, as opposed to report by this same author.

Before initiating treatment, the majority of patients showed incipient periodontal disease detected trough the Salivaster ${ }^{\circledR}$ test, possibly caused by crowding, which in the majority of patients is the principal motivation for the orthodontic treatment. Likewise, a significant increase of periodontal disease was observed 1 month after initiating orthodontic therapy 
( $2.5 \mathrm{mg} / \mathrm{dL}$ of saliva). Inflammation of the adjacent connective tissue has been considered a consequence of the use of orthodontic bands, determining that the condition of the gum deteriorates during the treatment with fixed appliances, even in patients with good oral hygiene. (Lara-Carrillo et al., 2010a)

Checking the quality, $\mathrm{pH}$ and buffer capacity of saliva can be valuable as part of an overall clinical assessment, thus also monitoring bacterial counts, plaque and periodontal inflammation.

In conclusion, orthodontic treatment changes the oral environmental factors: promotes a major salivary stimulated flow and increases its buffer capacity and salivary $\mathrm{pH}$, which increase the anticaries activity of saliva. Plaque $\mathrm{pH}$ did not demonstrate significant changes before and 1-month into orthodontic treatment. The bacterial levels did not increase significantly in the first month of the orthodontic treatment but, the increased of retentive surfaces rinsed the bleeding in saliva by periodontal injury.

Patients with orthodontic appliances require special care in terms of prevention caries and periodontal disease. For optimal patient care, it is necessary to analyzed if the changes during orthodontic treatment persist or change upon discontinuation of treatment.

The following markers emerged as protective factors: patients without active caries injuries increased significantly stimulated salivary flow, buffer capacity, and salivary $\mathrm{pH}$, after placement orthodontic appliances.

In contrast, the following markers were negative risk factors to the oral environment: slightly increase in the infection levels of SM and Lactobacillus, and of occult blood in saliva.

Oral environment has the capacity of adjustment to the presence of a foreign body, increasing the salivary flow which contributes to the autoclisis and modifying the salivary composition to raise the $\mathrm{pH}$ and buffer capacity, it prevents colonization by potentially pathogenic microorganisms by denying them optimization of environmental conditions.

It is necessary to establish the parameters that the patient presents at the beginning and during the treatment, and determine which stages may show major changes, if these changes are kept or reversed during the course of the therapy, with the purpose of preventing in an opportune and effective way.

So it is advisable to develop a prevention protocol for the development of dental caries or enamel demineralization in patients at risk, as is the case of those who undergo orthodontic treatment with fixed appliances.

It is recognized that this type of treatment has the potential to cause damage to hard and soft tissues of the oral cavity. In patients undergoing orthodontic treatment with fixed appliances increases bacterial counts due to the favorable environment for the accumulation of plaque and food debris that increase the risk of tooth decay, coupled with the difficulty of plaque removal by conventional means of oral hygiene.

However, the best way to combat tooth decay and periodontal disease is the strict control of plaque, for which it has recommended the use of electric toothbrushes, mouthwashes, oral irrigators, and others. But one of the most important parts to maintain oral health is the motivation of the patient. 
In this study it was observed that most patients showed interest in the results of their samples, from the very beginning knew the purpose of continually assessing their clinical characteristics, salivary and bacterial, asked if he had improved his health and brushing frequently controlled by plaque control record.

Because orthodontic appliances patients with an increased risk of tooth decay and/or periodontal disease problems, it is necessary to reduce the time in which these patients are at risk, the clinician will have the commitment of the good course of treatment, but the patient also plays an important role.

Another recommendation is to give greater publicity to the importance of oral health markers studied here can not only be applied in orthodontic patients, but in any patient is desirable to determine the risk of cavities that may have to take action convenient and proper preventive their clinical characteristics, salivary or bacterial infections, and especially those in which systemic disease is added.

\section{References}

Anderson P., Hector M.P. \& Rampersad M.A. (2001). Critical pH in resting and stimulated whole saliva in groups of children and adults. International Journal of Paediatric Dentistry, Vol. 11, No.4 (July, 2001), pp. 266-273, ISSN 0960-7439.

Ansai T., Yamashita Y., Shibata Y., Katoh Y., Sakao S., Takamatsu N., Miyasaki H. \& Takehara T. (1994). Relationship between dental caries experience of a group of Japanese kindergarten children and the results of two caries activity tests conducted on their saliva and dental plaque. International Journal of Paediatric Dentistry, Vol. 4, No.1 (March, 1994), pp. 13-17, ISSN 0960-7439.

Anusavice K.J. (2005). Present and future approaches for the control of caries. Journal of Dental Education, Vol. 69, No. 5 (May, 2005), pp. 538-554, ISSN 0022-0337.

Bollen A.M., Cunha-Cruz J., Bakko D.W., Huang G.J. \& Hujoel P.P. (2008). The effects of orthodontic therapy on periodontal health. A systematic review of controlled evidence. Journal of the American Dental Association, Vol. 139, No. 4 (April 2008), pp 413-422, ISSN 0002-8177.

Bretz W.A., do Valle E.V., Jacobson J.J., Marchi F., Mendes S., Nor J.E., Cancado M.F. \& Schneider L.G. (2001). Unstimulated salivary flow rates of young children. Oral Surgery, Oral Medicine, Oral Pathology, Oral Radiology and Endodontics, Vol 91, No. 5 (May 2001), pp 541-545, ISSN 1079-2104.

Butler B.L., Morejon O. \& Low S.B. (1996). An accurate, time-efficient method to assess plaque accumulation. Journal of the American Dental Association, Vol. 127, No. 12 (December 1996), pp 1763-1766, ISSN 0002-8177.

Chang H.S., Walsh L.J. \& Freer T.J. (1999). The effect of orthodontic treatment on salivary flow, $\mathrm{pH}$, buffer capacity, and levels of mutans streptococci and lactobacilli. Australian Orthodontic Journal, Vol. 15, No. 4 (April 1999), pp 229-34, ISSN 05873908.

Dawes C. (2003). What is the critical $\mathrm{pH}$ and why does a tooth dissolve in acid? Journal of the Canadian Dental Association, Vol. 69, No. 11 (December 2003), pp 722-724, ISSN 0709-8936. 
De Vigna A.P., Trindade G.A.M., Naval M.M.A., Soares L.A.A. \& Reis A.L. (2008). Saliva composition and functions: A comprehensive review. The Journal of Contemporary Dental Practice, Vol. 9, No. 3 (March 2008), pp 72-80, ISSN 1526-3711.

Derks A., Kuijpers-Jagtman A.M., Frencken J.E., Van't Hof M. \& Katsaros Ch. (2007). Caries preventive measures used in orthodontic practices: An evidence-based decision? American Journal of Orthodontics and Dentofacial Orthopedics, Vol. 132, No. 2 (August 2007), pp 165-170, ISNN 0889-5406.

Featherstone J. (2000). The science and practice of caries prevention. Journal of the American Dental Association, Vol. 131, No. 7 (July 2000), pp 887-899, ISSN 0002-8177.

Fenoll-Palomares C., Muñoz-Montagud J.V., Sanchiz V., Herreros B., Hernández V., Mínguez M. \& Benages A. (2004). Unstimulated salivary flow rate, $\mathrm{pH}$ and buffer capacity of saliva in healthy volunteers. Revista Española de Enfermedades Digestivas, Vol. 96, No. 11 (November 2004), pp 773-783, ISSN 1130-0108.

Gwinnett A.J. \& Ceen R.F. (1979). Plaque distribution on bonded brackets: a scanning microscope study. American Journal of Orthodontics and Oral Surgery, Vol. 75, No. 6 (June 1979), pp 667-677, ISSN 0002-9416.

Harris N. \& García-Godoy F. (2001). Preventive primary dentistry (2nd edition), Editorial El Manual Moderno, ISBN 0-83857898-5, México. [In Spanish].

Hashimoto M., Yamanaka K., Shimosato T., Ozawa A., Takigawa T., Hidaka S., Sakai T \& Noguchi T. (2006). Oral condition and health status of elderly 8020 achievers in Aichi Prefecture. The Bulletin of Tokyo Dental College, No. 47, vol. 2 (May 2006), pp 37-43, ISSN 0040-8891.

Heintze S.D., Finke C, Jost-Brinkman P-G \& Miethke R.R. (1999). Oral Health for the Orthodontic patient. Quintessence Publishing Co., ISBN 0-86715-295-8, Hong Kong.

Jensen B., Bratthall D. (1989). A new method for the estimation of Mutans Streptococci in human saliva. Journal of Dental Research, Vol. 68, No. 3 (March 1989), pp 468-471, ISSN 0022-0345.

Katz S, Mc Donald J.L., Stookey G.K. (1997). Preventive dentistry in action. Editorial Panamericana, ISBN 968-7157-08-9, México. [In Spanish].

Kaufman E. \& Lamster I. (2000). Analysis of saliva for periodontal diagnosis- a review. Journal of Clinical Periodontology, Vol. 27, No. 7 (July 2000), pp 453-465, ISSN 03036979.

Klaus H., Rateitschak E.M \& Wolf H.F. (1991). Pedodontics Atlas (2nd edition), Salvat, ISBN 84-345-2535-6, Barcelona. [In Spanish].

Kornman K.S. (2005). Diagnostic and prognostic tests for oral disease: practical applications. Journal of Dental Education, Vol. 69, No. 5 (May, 2005), pp. 498-508, ISSN 0022-0337.

Lara-Carrillo E., Montiel-Bastida N.M., Sánchez-Pérez L., Alanís-Tavira J.(2010). Changes in the oral environment during four stages of orthodontic treatment. Korean Journal of Orthodontics, Vol. 40, No. 2 (April 2010), pp 95-105, ISSN 1225-5610.

Lara-Carrillo E., Montiel-Bastida N.M., Sánchez-Pérez L., Alanís-Tavira J. (2010). Effect of orthodontic treatment on saliva, plaque and the levels of Streptococcus mutans and Lactobacillus. Medicina Oral Patología Oral y Cirugía Bucal, Vol. 15, No. 6 (November 2010), pp 924-9, ISSN 1698-4447.

Larmas M. (1992). Saliva and dental caries: diagnostic tests for normal dental practice. International Dental Journal, Vol. 42, No. 4 (August 1992), pp 199-208, ISSN 00206539. 
Leone C.W. \& Oppenheim F.G. (2001). Physical and chemical aspects of saliva as indicators of risk for dental caries in humans. Journal of Dental Education, Vol. 65, No. 10 (October, 2001), pp. 1054-1061, ISSN 0022-0337.

Menaker L., Mohart R.E. \& Navia J.M. (1986). Biological basis of dental caries, Salvat, ISBN 84345-2142-3, Barcelona. [In Spanish].

Migale D., Barbato E., Bossú M., Ferro R., Ottolenght L. (2009). Oral health and malocclusion in 10 to 11 years-old children in southern Italy. European Journal of Paediatric Dentistry, Vol. 10, No. 1 (March 2009), pp 13-18, ISSN 1591-996X.

Monterde C.M.E., Delgado R.J.M., Martínez R.I.M., Guzmán F.C.E., Espejel M.M. (2002). Demineralization-remineralization in the dental enamel. Revista ADM, Vol. 59, No. 6 (November-December 2002), pp 220-222, ISSN 0001-0944. [In Spanish].

Moynihan P. J. (2005). The role of diet and nutrition in the etiology and prevention of oral diseases. Bulletin of the World Health Organization, Vol. 83, No. 9 (September 2005), pp 694-699, ISSN 0042-9686.

Munshi A.K., Hedge A.M. \& Munshi A. (1999). Relationship between the existing caries status, plaque, S. mutans and Cariostat caries activity test in children. Journal of Indian Society of Pedodontics and Preventive Dentistry, Vol. 17, No. 3 (September 1999), pp 73-89, ISSN 0970-4388.

National Institutes of Health Consensus Development conference statement. (2001). Diagnosis and management of dental caries throughout life, march 26-28. Journal of the American Dental Association, Vol. 132, No. 8 (August 2001), pp 1153-1161, ISSN 0002-8177.

Nishimura M., Bhuiyan M.M., Matsumura S \& Shimono T. (1988). Assessment of the caries activity test (Cariostat) based on the infection levels of mutans streptococci and lactobacillos in 2 to 13 year old children's dental plaque. ASDC Journal of Dentistry for Children, Vol. 65, No. 4 (July-August 1988), pp 248-251, ISSN 1945-1954.

Nishimura M., Oda T., Kariya N., Matsumura S. \& Shimono T. (2008). Using a caries activity test to predict caries risk in early childhood. Journal of the American Dental Association, Vol. 139, No. 1 (January 2008), pp 63-71, ISSN 0002-8177.

Niwa M. \& Fukuda M. (1989). Clinical study on the control of dental plaque using a photo energy conversion a toothbrush equipped with a $\mathrm{TiO}_{2}$ semiconductor. Shigaku, Vol. 77, No. 2 (August 1989), pp 1-16, ISSN 0029-8484.

O' Leary T.J., Drake R.B. \& Naylor J.E. (1972). The plaque control record. Journal of Periodontology, Vol. 43, No. 1 (January 1972), pp 38, ISSN 0022-3492.

Prieto V.J.M. \& Yuste J.R. (2010). Balcells. The clinic and the laboratory. Interpretation of analysis and functional tests (21st edition), Elsevier Masson, ISBN 9-78844-582030-8, España. [In Spanish].

Proffit W.R. (2008). Contemporary Orthodontics. (4th. Edition), Elsevier Mosby, ISBN 978-848086-330-8, España. [In Spanish].

Sánchez P.L. \& Sáenz M.L.P. (2003). A comparison between risk caries indicators. Boletin Médico del Hospital Infantil de México. No. 60, Vol. 3, (May-June 2003), pp 263-273, ISSN 1665-1146. [In Spanish]

Sánchez P.T.L. \& Sáenz M.L.P. (1998). Caries experience as predictors of disease at 18 months. Revista ADM, Vol. 55, No. 6 (November-December 1998), pp 283-286, ISSN 0001-0944. [In Spanish]. 
Saroglu S. \& Aras S. (2007). Effect of white cheese and sugarless yoghurt on dental plaque acidogenicity. Caries Research, Vol. 41 No. 3 (March 2007), pp 208-211, ISSN 00086568.

Sidlauskas A. \& Lopatiené K. (2009). The prevalence of malocclusion among 7-15 years-old Lithuanian schoolchildren. Medicina (Kaunas), Vol. 45 No. 2 (February 2009), pp 147152, ISSN 1010-660X.

Tanzer J.M., Livingston J. \& Thompson A. (2001). The microbiology of primary dental caries in humans. Journal of Dental Education, Vol. 65, No. 10 (October, 2001), pp. 10281037, ISSN 0022-0337.

Torres S.R., Nucci M., Milanos E., Pessoa P.R., Massaud A. \& Munhoz T. (2006). Variations of salivary flow rates in Brazilian school children. Brazilian Oral Research, Vol. 20 No. 1 (January-March 2006), pp 8-12, ISSN 1806-8324.

Trulsson U., Strandmark M., Mohlin B. \& Berggren U. (2002). A qualitative study of teenagers' decision to undergo orthodontic treatment with fixed appliance. Journal of Orthodontics, Vol. 29, No. 3 (September 2002), pp 197-204, ISSN 1465-3125.

Turbill E.A., Richmond S. \& Wright J.L. (2001). The time-factor in orthodontics: What influences the duration of treatments in National Health Service practices? Community Dentistry and Oral Epidemiology, Vol. 29 No. 1 (February 2001), pp 62-72, ISSN 0301-5661.

Varma S., Banerjee A. \& Bartlett D. (2008). An in vivo investigation of associations between saliva properties, caries prevalence and potential lesion activity in an adult UK population. Journal of Dentistry, Vol. 36 No. 4 (April 2008), pp 294-299, ISSN 03005712.

WHO Oral Health Country/Area Profile Programme. (July 17, 2011). Caries prevalence: DMFT and DMFS. August 23, 2011, Available from: http://www.mah.se/CAPP/Methods-and-Indices/for-Caries-prevalence/

WHO Oral Health Country/Area Profile Programme. (July 5, 2011). The plaque control record (O'Leary T, Drake R, Taylor, 1972). August 23, 2011, Available from: http://www.mah.se/CAPP/Methods-and-Indices/Oral-Hygiene-Indices/PlaqueControl-Record/

World Health Organization. (1997). Oral Health Surveys. Basic methods. (4th edition), W.H.O, ISNB 9-78924-154493-1, Geneva.

Zárate D.A.S., Leyva H.E.R. \& Franco M.F. (2004). Determination of pH and total proteins in saliva in patients with and without fixed orthodontic appliances (pilot study). Revista Odontológica Mexicana, Vol. 8 No. 3 (September 2004), pp 59-63 ISSN 1870199X. [In Spanish]. 


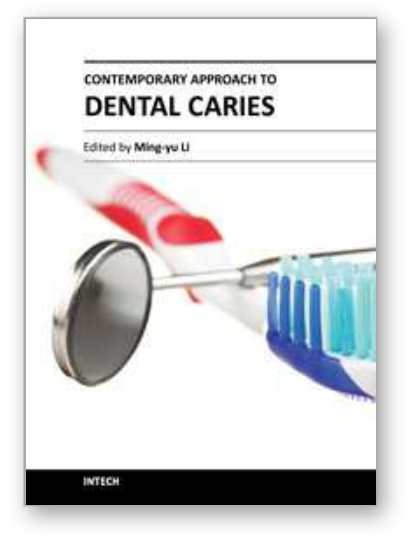

\author{
Contemporary Approach to Dental Caries \\ Edited by Dr. Ming-Yu Li
}

ISBN 978-953-51-0305-9

Hard cover, 488 pages

Publisher InTech

Published online 14, March, 2012

Published in print edition March, 2012

With an update of the recent progress in etiology, pathogenesis, diagnosis, and treatment of caries, it may be said that the final defeat of dental caries is becoming possible soon. Based on the research in this area in recent decades, "Contemporary Approach to Dental Caries" contained the caries in general, the diagnosis of caries, caries control and prevention, the medical treatment of caries, dental caries in children and others such as secondary caries. This book provides the reader with a guide of progress on the study of dental caries. The book will appeal to dental students, educators, hygienists, therapists and dentists who wish to update their knowledge. It will make you feel reading is profitable and useful for your practice.

\title{
How to reference
}

In order to correctly reference this scholarly work, feel free to copy and paste the following:

Edith Lara-Carrillo (2012). Clinical, Salivary and Bacterial Markers on the Orthodontic Treatment, Contemporary Approach to Dental Caries, Dr. Ming-Yu Li (Ed.), ISBN: 978-953-51-0305-9, InTech, Available from: http://www.intechopen.com/books/contemporary-approach-to-dental-caries/clinical-salivary-andbacterial-markers-on-the-orthodontic-treatment

\section{INTECH}

open science | open minds

\section{InTech Europe}

University Campus STeP Ri Slavka Krautzeka 83/A 51000 Rijeka, Croatia Phone: +385 (51) 770447

Fax: +385 (51) 686166 www.intechopen.com

\section{InTech China}

Unit 405, Office Block, Hotel Equatorial Shanghai No.65, Yan An Road (West), Shanghai, 200040, China 中国上海市延安西路65号上海国际贵都大饭店办公楼 405 单元 Phone: +86-21-62489820

Fax: $+86-21-62489821$ 
(C) 2012 The Author(s). Licensee IntechOpen. This is an open access article distributed under the terms of the Creative Commons Attribution 3.0 License, which permits unrestricted use, distribution, and reproduction in any medium, provided the original work is properly cited. 